\title{
Health Care Decision Making and Physician-Aid-IN-Dying in HawaII
}

\author{
James H. Pietsch, J.D. \\ "Death has not been managed as well as it could be ...."
}

\section{INTRODUCTION}

Lamentations on end-of-life care in Hawaii may well be a cliché for the debate over death and dying across the nation. Clichés, however, can mask true human tragedy and genuine concern for life and its aversion to human suffering.

Dying people in Hawaii and elsewhere face hidden individual tragedies on a daily basis. Investigations into the root causes of problems in care at the end of life have not so far resulted in necessary corrections. In many ways, Hawaii is a special place, ${ }^{2}$ but it joins the other states in continuing to grapple with end-of-life decision-making issues. With the introduction of new, yet familiar, bills in upcoming legislative sessions, Hawaii may or may not regain its "special" status as being a state where issues of living and dying with dignity are taken seriously and addressed compassionately.

This article suggest that the Aloha State may be ready for legislation that would authorize the practice of Physician-Aid-In-Dying, both PhysicianAssisted Suicide (PAS) and even perhaps Physician-Assisted Dying (PAD), ${ }^{3}$

\footnotetext{
${ }^{*}$ Professor of Law, William S. Richardson School of Law and Adjunct Professor of Geriatric Medicine, John A. Burns School of Medicine. University of Hawaii at Manoa; Director, University of Hawaii Elder Law Program; Member, the Governor's Blue Ribbon Panel on Living and Dying with Dignity. The author wishes to acknowledge and thank Scott Suzuki, J.D. (2004), William S. Richardson School of Law, for his assistance with this article. Address correspondence to Professor Pietsch at William S. Richardson School of Law, 2515 Dole Street, Honolulu, HI 96822-2328, or via e-mail at jpietsch@hawaii.edu.

' Final Report of the Governor's Blue Ribbon Panel on Living and Dying with Digntty (Honolulu, Hawaii, May 1998).

${ }^{2}$ Former Hawaii Governor George Ariyoshi (1977-1986) was famous for describing Hawaii as a special place. He would describe it as more nearly a nation than any other state, a statement that, in light of a current re-energized sovereignty movement, may have been prescient.

${ }^{3}$ The term Physician-Assisted Suicide (PAS) is used generally when a physician provides a competent patient who requests it with a prescription for medicine for the patient to use with the primary intention of ending his or her own life. Physician-Assisted Death (PAD) is generally used when a physician gives a competent dying patient who requests it a lethal injection with the primary intention of ending the patient's life.
} 
given the context of Hawaii's unique history, demographic diversity, climate of tolerance, spirit of community cooperation, and support for personal freedom. Hawaii is used here as an example because its ongoing debate about PAS and PAD may prove enlightening to other states that are facing similar life and death issues.

Although there is no explicit legal right to PAS or PAD in Hawaii, there also is no doubt that these practices exist. ${ }^{4}$ There is some doubt, however, about whether PAS and PAD actually are illegal in the state. This article provides background discussion about the legal climate for making health care decisions in Hawaii. It then provides information about the attitudes of groups and individuals and initiatives in Hawaii since the issuance of the Governor's Blue Ribbon Panel on Living and Dying with Dignity Final Report, and compares end-of-life activities in Hawaii to another United States jurisdiction (Oregon) and a foreign jurisdiction (the Netherlands) that have enacted legislation giving certain residents the right to request physician aid in dying by means of lethal medication. ${ }^{5}$

\section{HAWAII'S HISTORY OF LAWS PROMOTING INDIVIDUAL RIGHTS}

Hawaii has a history of increasingly progressive laws. It started with King Kamehameha the Great and his "Law of the Splintered Paddle," Kanawai Mamalahoe. This first law is incorporated into the current state constitution. ${ }^{6}$ Since the time of King Kamehameha the Great, Hawaii has continued its history of progressive laws to protect its residents. One example is a provision of Hawaii's Constitution that incorporates the so-called "privacy provision": "The right of the people to privacy is recognized and shall not be infringed without the showing of a compelling state interest."

\footnotetext{
${ }^{4}$ Personal communications with physicians who were on the Governor's Blue Ribbon Committee on Living, Dec. 1997. See also FINAL REPORT, supra note 1, at 27; Editorial, Suicide Bill: Weary of the Post-Mortems, Honolulu Advertiser, Mar. 15, 2004, at A8. What constitutes "assisted suicide" is not always clear. "[A] subtle form of assisted suicide is already practiced in hospitals when doctors and nurses halt life-sustaining treatments in hospitals to let a terminally ill patient die. Moreover, as part of palliative care, narcotics administered to relieve pain can occasionally result in sufficient respiratory depression to kill a patient." Id.

5 This article does not delve into ancillary, but nonetheless integral, matters such as the influence and role of the federal Drug Enforcement Administration on issues relating to the use of controlled substances that may be used in PAS and PAD. Nor does this article discuss the influence and role of state regulatory entities such as state Departments of Health, Attomeys General, or Boards of Medical Examiners.

${ }^{6} \mathrm{HAW}$. CONST. art. IX, $\S 10$ ("The law of the splintered paddle, mamala-hoe kanawai, decreed by Kamehameha I-Let every elderly person, woman and child lie by the roadside in safety-shall be a unique and living symbol of the State's concern for public safety.")

${ }^{7} I d$. art. I, $\$ 6$.
} 
In the context of health care decision making, this provision has been cited as a basis for upholding the right of a person (or a guardian for an incompetent person) to refuse unwanted medical treatment. ${ }^{8}$ Relying on this state constitutional provision, Hawaii has been able to codify several other progressive individual rights.

In another privacy-related development, Hawaii was the first state to authorize abortion. After losing a number of its young women to botched abortions through the decades, Hawaii legalized abortion in $1970,{ }^{9}$ three years before the United States Supreme Court's watershed Roe v. Wade decision. ${ }^{10}$

In 1974, Hawaii was the first state to enact employer-mandated health insurance legislation. ${ }^{11}$ That Act provided that all employees in Hawaii who worked at least 20 hours per week would have access to health care.

Both the abortion law and employer-mandated health insurance indicate a trend in the way Hawaii has addressed controversial medical issues. Other laws indicated Hawaii's traditional treatment of individual rights. Perhaps the most relevant of these is an 1896 statute describing the rights of patients to seek relief from suffering. Originally this law provided as follows:

[W] hen a duly licensed physician pronounces a person afflicted with any disease hopeless and beyond recovery and gives a written certificate to that effect to the person afflicted or to his or her attendant nothing herein shall be held or construed to forbid any person from giving or furnishing any remedial agent or measure when so requested by or on behalf of the afflicted person. ${ }^{12}$

\footnotetext{
${ }^{8}$ In re Guardianship of Crabtree, Cause No. 86-0031 (Haw. Fam. Ct., 1st Cir. Apr. 26, 1990).

${ }^{9}$ Haw. Rev. Stat. §453-16 (1970).

10410 U.S. 113 (1973).

${ }^{11}$ Haw. Rev. Stat. $\$ 393-7$ (1993). In 2003, the Hawaii legislature amended this section, without affecting the provisions described herein. 2003 Hawaii Laws Act 206 (S.B. 665) (2003).

${ }^{12}$ See 89 Rev. Laws of HawaII $\S 1069$ (1909). Section 1069 stated in full:
}

Section 1069. Practice of Medicine Defined. For the purposes of this Chapter the practice of medicine shall be held to include the use of drugs and medicines, water, electricity, hypnotism, or any means or method, or any agent, either tangible or intangible, for the treatment of disease in the human subject; provided, however, that nothing herein contained shall be held to forbid any person from the practice of any method or the application of any remedial agent or measure under the direction or with the approval of a licensed physician; and provided further, that when a duly licensed physician pronounces a person afflicted with any disease hopeless and beyond recovery and gives a written certificate to that effect to the person afflicted or to his or her attendant nothing herein shall be held or construed to forbid any person from giving or furnishing any remedial agent or measure when so requested by or on behalf of the afflicted person.

The provisions of this Act shall not be construed to amend or repeal the law respecting leprosy or segregation.

Section 1069 is now codified at Haw. Rev. StaT. $§ 453-1$ (1984). It has been amended over the years but retains the essential provisions of the 1909 law. It currently reads as follows:

\$453-1. Practice of medicine defined. For the purposes of this chapter the practice of medicine includes the use of drugs and medicines, water, electricity, hypnotism, or any means or method, 
These laws, although not comprehensive, are indicative of the progressive nature of the Hawaii legislature on issues of individual rights. Further, they show the deference the state gives to personal autonomy in medical matters. The question remains, however, how far Hawaii may go to authorize PAS and PAD and, even if there is no explicit authorization, whether Hawaii law already provides some protection for those who seek to end their lives with the assistance of a physician. The following sections discuss where Hawaii currently stands in relation to that question.

\section{OVERVIEW OF HEALTH CARE DECISION MAKING IN HAWAII}

Although Hawaii does not explicitly give persons the legal right to make the decision to terminate their own lives, it does have a number of laws that help to assure health care providers will carry out a patient's wishes, including an intention to withdraw or withhold medical treatment and alleviate undue suffering. These laws do not specifically authorize a person to consent to PAD even if fully informed. At the same time, if future legislation should permit PAD, the requirement of informed consent will be a necessary safeguard to help prevent abuse.

\section{A. Informed Consent}

As in other jurisdictions, health care decisions are made every day in Hawaii by patients or their authorized representatives, along with their physicians or other health care providers. Over the years, it has become increasingly important to address not only what health care an individual wants, but also how decisions are made and enforced when the patient is unable personally to make informed decisions. As in other states, a combination of laws impact health care decision making in Hawaii.

Across the country, the process for making medical treatment decisions revolves around the concepts of informed consent and a person's constitutional right to accept or refuse unwanted medical treatment. In general and with few exceptions, the United States Constitution and the common law provide that an individual with decision-making capacity has the right to consent to or refuse any suggested medical treatment, even if refusal may result in death. ${ }^{13}$ Hawaii, like the other states, has treated this issue with relative consistency.

or any agent, either tangible or intangible, for the treatment of disease in the human subject; provided that when a duly licensed physician pronounces a person affected with any disease hopeless and beyond recovery and gives a written certificate to that effect to the person affected or to the person's attendant nothing herein shall forbid any person from giving or furnishing any remedial agent or measure when so requested by or on behalf of the afflicted person.

${ }^{13}$ See, e.g., U.S. Const. amend. XIV; Cruzan v. Director, Missouri Dep't of Health, 497 U.S. 261 (1990). 
To ensure that the patient's consent to treatment is informed, the Hawaii legislature has provided the Board of Medical Examiners the option, within certain boundaries, to establish standards for health care providers to follow in giving information to a patient, or to a patient's guardian or "surrogate" if the patient is not competent. ${ }^{14}$ These standards may include the substantive content of the information to be given, the manner in which the information is to be given by the health care provider, and the manner in which consent is to be given by the patient or guardian. ${ }^{15}$ The concept of informed consent continues to evolve but essentially revolves around a patient's right to have the opportunity to be an informed participant in his or her health care decisions. Discussions regarding the treatment or procedures normally include information regarding the patient's diagnosis, the nature and purpose of a proposed treatment or procedure, their attendant risks and benefits, alternative treatments or procedures and their attendant risks and benefits, and the risks and benefits of not receiving or undergoing a treatment or procedure. ${ }^{16}$

The doctrine of informed consent to treatment includes the right to informed refusal of treatment. A competent adult patient has the right to refuse all forms of medical intervention, including life-saving or life-prolonging treatment. ${ }^{17}$

Hawaii has adopted a patient-oriented standard applicable to the duty to disclose risk information prior to treatment. ${ }^{18}$ The patient-oriented standard of informed consent focuses on what reasonable patients objectively need to hear from the physician to allow them to make informed and intelligent decisions regarding proposed medical treatment. ${ }^{19}$

\section{B. Hawaii's Uniform Health Care Decisions Act (Modified)}

For the most part, Hawaii's Uniform Health Care Decisions Act (Modified), or UHCDA, follows a model act developed by the National Conference of Commissioners on Uniform State Laws (NCCUSL), but has a few provisions that are unique to Hawaii. The UHCDA takes a comprehensive

\footnotetext{
${ }^{14}$ See Haw. Rev. Star. $§ 671-3$ (1983). On January 1, 2004, Hawaii Laws Act 114 (H.B. 651) (2003) became effective. The Act amends section 671-3 substantially by recognizing "legal surrogates" for the purposes of making health care decisions. For the purposes of the Act, a "legal surrogate" is "an agent designated in a power of attorney for health care or a surrogate designated or selected in accordance with Chapter 327E."

${ }^{15}$ See Haw. Rev. Stat. $§ 671-3$ (1983).

${ }^{16}$ H.B. 651, 2003 Leg., 23rd Sess. (Haw. 2003) and S.B. 624, 2003 Leg., 23rd Sess. (Haw. 2003) were introduced in the 2003 legislative session to update Hawaii's informed consent laws. A compromise bill was passed and signed into law as Act 114 (Haw. Sess. Laws 114, 2003). In brief, the changes to the law, effective January 2004, included changes to update Hawaii law to make it more consistent with other laws and extending the right to consent to or refuse medical treatment to legal guardians or surrogates.

${ }^{17}$ See Cruzan, 497 U.S. at 278-79 (assuming, and strongly suggesting, that the Fourteenth Amendment Due Process clause protects the traditional right to refuse unwanted lifesaving medical treatment).

${ }^{18}$ Carr v. Strode, 904 P.2d 489 (Haw. 1995).

${ }^{19}$ Id. This case overruled the prior standard as expressed in Nishi v. Hartwell, 473 P.2d I 16 (Haw. 1970).
} 
approach by placing the so-called "living will," 20 the durable power of attorney for health care, a "family consent" or surrogate law, and some provisions concerning organ donation together in one statute. The new "individual instruction," which takes the place of what is commonly called the "living will," applies to a wide range of health care decisions, not just end-of-life decisions. The residual decision-making portion of the Act is somewhat like family consent statutes that have been adopted in a majority of states. This section of the Act applies only if there is no applicable individual instruction, guardian, or appointed agent. Hawaii has established a unique framework for appointing or selecting surrogates. In Hawaii, there is no established hierarchy for surrogates.

Under the law, an adult or emancipated minor may make advance health care directives $^{21}$ by giving an "individual instruction" 22 orally or in writing and/or by executing a power of attorney for health care, which may authorize the agent to make any health care decision the principal could have made while having capacity. An individual may revoke the designation of an agent only by a signed writing or by personally informing the supervising health care provider, ${ }^{23}$ but an individual may revoke all or part of an advance health care directive, other than the designation of an agent, at any time and in any manner that communicates an intent to revoke. ${ }^{24}$ The law even provides an optional sample form (and explanation), which may be duplicated or modified to suit the needs of the person. Alternately, one may use a completely different form that contains the substance of the sample form found in the statute. ${ }^{25}$

Under the UHCDA, a surrogate may make a health care decision for a patient if the patient lacks capacity and no agent or guardian has been appointed or neither the agent nor guardian is available. ${ }^{26} \mathrm{~A}$ patient may designate or disqualify any individual to act as a surrogate by personally informing the supervising health care provider. ${ }^{27}$ In the absence of such a designation, or if the designee is not reasonably available, a surrogate may be appointed to make a health care decision for the patient. ${ }^{28}$ Unlike the Uniform Act approved by the NCCUSL, Hawaii's modified version of the UHCDA does not provide for the more common approach of a hierarchy of decision makers for a decisionally incapacitated patient, but instead provides for decision making by surrogates selected from a group of "interested persons." 29

\footnotetext{
${ }^{20}$ Nowhere in the statute is the term "living will" used.

${ }^{21}$ Haw. Rev. Stat. \$327E-3 (1999).

${ }^{22} \mathrm{Id}$. $\S 327 \mathrm{E}-2$ (defining an "Individual Instruction" as an individual's direction concerning a health care decision for the individual).

${ }^{23}$ Id. $\$ 327 \mathrm{E}-34$ (a).

${ }^{24}$ Id. $\$ 327 \mathrm{E}-4$ (b).

$25 I d . \$ 327 \mathrm{E}-16$.

${ }^{26} I d$. $\$ 327 \mathrm{E}-2$ (defines"capacity" as an individual's ability to understand the significant benefits, risks, and alternativies to proposed health care and to make and communicate a health care decision).

${ }^{27}$ Id. $\$ 327 \mathrm{E}-5$ (a).

${ }^{28}$ Id. $\S 327 \mathrm{E}-5$ (b).

${ }^{29}$ Id.
} 
Under the Hawaii statute, "interested persons" means the patient's spouse, unless legally separated or estranged, a reciprocal beneficiary, any adult child, either parent of the patient, an adult sibling or adult grandchild of the patient, or any adult who has exhibited special care and concern for the patient and who is familiar with the patient's personal values. ${ }^{30}$ As explained above, the patient can designate or disqualify a surrogate. Accordingly, interested persons can be "trumped" by an orally designated surrogate. In the same manner, a patient may orally disqualify someone who otherwise might be entitled to make decisions on behalf of the patient.

Hawaii's version of the UHCDA places restrictions on decisions by "non-designated surrogates." nutrition and hydration may be withheld or withdrawn upon a decision by the surrogate only when the primary physician and a second independent physician certify in the patient's medical records that the provision of artificial nutrition or hydration is merely prolonging the act of dying and that the patient is highly unlikely to have any neurological response in the future." ${ }^{32}$ Neither PAS nor PAD is addressed in the surrogate section of the statute.

Hawaii's statute follows the UHCDA, for the most part, in dealing with decisions by guardians, obligations of health care providers, health care information, immunities, statutory damages, judicial relief, uniformity of application, and other administrative matters. Although this statute provides the framework for addressing and implementing medical treatment and other health care decisions, there are numerous issues that are not specifically addressed. For example, it is not clear whether a guardian, agent, or surrogate, if anyone, would have the authority to request assisted death on behalf of the principal. Further, it is not clear whether such a decision would be considered a "health care" decision or something altogether different.

\section{Diminished Capacity}

End-of-life health care decision making by legally authorized individuals for patients who have diminished capacity, and especially for those who are in comas or persistent vegetative states, can be difficult but is not uncommon. More difficult are issues that arise when an individual has diminished

\footnotetext{
${ }^{30} \mathrm{Id} . \S 327 \mathrm{E}-2$.

${ }^{31}$ Id. $\S 327 \mathrm{E}-5(\mathrm{e})$ (mentions a "surrogate who has not been designated").

${ }^{32}$ Id. $\$ 327 \mathrm{E}-5(\mathrm{~g})$. This particular provision has been the source of some confusion. There are several unanswered questions. Does "any neurological response" equate to something less than brain death and, if so, what? Must tube feeding be applied or continued for every patient who has a "non-designated" surrogate selected to make health care decisions if no definition of "any neurological response" can be agreed on by the medical community? Would seeking guardianship rather than selecting a "nondesignated" surrogate be an effective means of circumventing the limitations?
} 
capacity but is not in a coma or persistent vegetative state and a decision about terminating treatment is in the balance. The key issue is the individual's decisional capacity to make and communicate decisions. ${ }^{33}$

Determining decisional capacity is not an exact science. ${ }^{34}$ Although there is no Hawaii appellate case directly on point, a 2001 California case illustrates the complexity of making health care decisions for individuals with diminished capacity. The following brief outline of that case serves to show the difficulty of these issues. Anecdotal evidence indicates that several similar cases have occurred in Hawaii.

Robert Wendland was severely injured in an automobile accident in 1993. The accident caused paralysis and brain damage, which made it necessary for Mr. Wendland to receive sustenance through a nasogastric feeding tube inserted through his nose, down his esophagus, and into his stomach. Although physicians did not diagnose him as being in a coma or persistent vegetative state, he was considered unable to communicate concerning his own care. His condition has been described as a "minimally conscious state," or MCS. ${ }^{35}$

After two years, his wife of 15 years made a decision to withdraw his feeding tube. She claimed that he had told her previously that he would not want to be kept alive in a condition of total dependence. His physicians provided evidence that he would never recover sufficient mental capacity to make decisions. His situation was referred to a hospital ethics committee, which agreed that it would be permissible to withdraw the feeding tube and allow him to die. Mr. Wendland's mother and sister objected and filed an action in court to prevent the withdrawal of the feeding tube. After several years, the California Supreme Court finally decided the case. The state supreme court upheld a trial court decision that, applying a clear and convincing evidence standard, had found the evidence insufficient and thus had denied the conservator's request for authority to withhold artificial nutrition and hydration. ${ }^{36}$

If Mr. Wendland had executed an advance directive that carefully delineated the decisions to be made, under what circumstances they were to be carried out, and who would be given the legal authority to carry out his instructions, then the case might not have ended up in court. Likewise, in Hawaii, if a person executes an advance directive under the UHCDA and makes clear his

${ }^{33} I d . \$ 327 \mathrm{E}-3$.

${ }^{34}$ See, e.g., Robert P. Roca, Determining Decisional Capacity: A Medical Perspective, 62 FoRdHAM L. REV. 1177 (1994)

${ }^{35}$ See, e.g., Joseph Giacino et al., The Minimally Conscious State: Definition and Diagnostic Criteria, 58 Neurologr 349 (2002). MCS is characterized by inconsistent but clearly discernible behavioral evidence of consciousness and can be distinguished from coma and vegetative state by documenting the presence of specific behavioral features not found in either of these conditions. Patients may evolve to MCS from coma or vegetative state after acute brain injury. This condition often is transient, but also may exist as a permanent outcome.

${ }^{36}$ Conservatorship of Wendland, 28 P.3d 151 (Cal. 2001). 
or her directions, health care providers are legally protected for following the instructions. These requirements not only provide legal protections for physicians and other health care providers who follow a patient's wishes, but also impose sanctions on those who do not follow the instructions of authorized decision makers.

Anecdotal evidence seems to establish, however, that family courts in Hawaii ${ }^{37}$ have been willing to grant requests of third parties seeking to prolong life support, including artificial hydration and nutrition for incapacitated persons, when patients' advance directives are not clear or contain conditions that can be difficult to meet with medical certainty. For example, a patient may have an advance directive, made under subsequently repealed law, that states that it goes into effect only when the patient is unable to communicate medical treatment decisions and "there is little likely chance of recovery." 38 It may not be difficult to convince a judge that the condition has not been met, especially because it is not hard to find another physician to testify that there is always a chance that the patient will recover.

There also is continuing anecdotal evidence of physicians in Hawaii who do not follow the advance directives of their patients, even though they are provided broad protections for complying with decisions of authorized decision makers. ${ }^{39}$ Seemingly in response, more attorneys are taking an interest in addressing non-compliance and enforcing sanctions against health care providers who refuse to follow patients' directives. ${ }^{40}$ Health care providers, institutions, and other interested persons also can seek court intervention if they believe that the treatment is inappropriate. ${ }^{41}$

\section{Hawaii's Comfort Care Only/Do Not Resuscitate (CCO-DNR) Orders}

Advance health care directives (such as the old "living will" and newer "individual instructions for health care" and "durable powers of attorney for health care") often are not very useful when a patient suffers cardiac or respiratory arrest. In a hospital or other health care facility setting, a patient who suffers an arrest routinely is resuscitated unless there is a written "DNR" (do not resuscitate) order in the medical record. The DNR order is an instruction to only withhold the otherwise automatic initiation of cardiopulmonary resuscitation and it should not affect other forms of treatment. Outside a health care facility, emergency response personnel normally attempt to resuscitate

\footnotetext{
${ }^{37}$ See HAW. REv. Stat. $\$ 560: 5$ (1977). Family courts in Hawaii generally have jurisdiction over health care decision making and guardianship of the person actions.

38 See Haw. Rev. Stat. §327D (1999).

${ }^{39}$ See id. $\S 327 \mathrm{E}-9$.

${ }^{40} / d . \S 327 \mathrm{E}-10$.

${ }^{41}$ Id. $\$ 327 \mathrm{E}-14$.
} 
an individual who suffers a cardiac or respiratory arrest. This may or may not be the course of action that the individual would request if he or she still could make and express a choice. ${ }^{42}$

In the past few years, legislation has been introduced intended to remove the terminal condition requirement, as well as the strict requirements to utilize particular forms and procedures. Proposed changes to the law would make it easier for patients to obtain CCO-DNR bracelets or necklaces and for agents or surrogates to make decisions on behalf of incapacitated persons. ${ }^{43}$ The 2003 legislature did not implement these proposed changes. It was carried over to the 2004 session, but it was deferred again.

\section{LEGAL AUTHORITY FOR ASSISTED SUICIDE}

\section{A. Judicial Background}

In 1990, the United States Supreme Court held in Cruzan v. Director, Missouri Department of Healt $h^{44}$ that a competent person has a liberty interest under the Due Process clause to refuse unwanted medical treatment. This has become the basis of many of the current laws around the nation relating to health care decisions.

The Supreme Court in Cruzan assumed that a competent person's right to make medical decisions includes a right to refuse life-sustaining artificial hydration and nutrition. ${ }^{45}$ The Court refused to extend the same right to an incompetent person, because such a person is unable to make an informed and voluntary choice. The Court further stated that the Due Process clause does not require a state to accept the "substituted judgment" of close family members that artificial nutrition and hydration should be withdrawn or withheld, in the absence of clear and convincing evidence that their views reflect the patient's views. $^{+6}$

${ }^{42}$ See id. $\$ 321-23.6$ (1994). This section allows a terminally ill person to state in advance that he or she does not want to be resuscitated in an emergency if he or she:

(a) has been certified in a written "comfort care only" document by the person's physician to be a terminally ill patient of that physician; and

(b) has certified in the same written "comfort care only" document that the person directs emergency medical services personnel, first responder personnel, and healthcare providers not to administer chest compression, rescue breathing, electric shocks, or medication, or all of these, given to restart the heart if the person's breathing or heart stops, and directs that the person is to receive care for comfort only, including oxygen, airway suctioning, splinting of fractures, pain medicine, and other measures required for comfort; and

(c) has been prescribed by a physician a "comfort care only" identifying bracelet or necklace.

${ }^{43}$ See H.B. 1182, 2003 Leg., 23rd Sess. (Haw. 2003), which was carried over to the 2004 session.

44497 U.S. 261 (1990).

$45 I d$. at 279.

${ }^{46} I d$. at 286. 
Using Cruzan as a backdrop, the Supreme Court later addressed the related issue of physician-aid-in-dying. In 1996, the Ninth Circuit Court of Appeals struck down Washington State's ban on physician-assisted suicide in Compassion in Dying v. State of Washington. ${ }^{47}$ Under the Washington statute, a person was guilty of promoting suicide if "he knowingly causes or aids another person to attempt suicide, $"$ " who assist terminally ill patients. The statute prohibited promoting suicide but did not address the issue of actually causing death or administering a fatal treatment. The Ninth Circuit declared the Washington statute unconstitutional and determined that the terminally ill had a right under the Fourteenth Amendment to a "dignified and humane death." The decision revolved around the right of terminally ill patients to die with the assistance of a physician.

The Court of Appeals adopted as the definition of physician-assisted suicide the "prescribing of medication by a physician for the purpose of enabling a patient to die." ${ }^{+9}$ Assisted suicide was differentiated from the voluntary removal of life support protected in Cruzan, because assisted suicide "involves not letting the patient die, but making the patient die." ${ }^{50}$

On certiorari, the United States Supreme Court reversed the Ninth Circuit. ${ }^{51}$ The unanimous decision declared that assisted suicide is not rooted in American history and generally is a criminal offense. ${ }^{52}$ The ultimate holding is that there is no constitutional right to assisted suicide. As a result, states reserve the right to criminally punish physicians who prescribe life-ending drugs to mentally competent but terminally ill patients who no longer want to live.

In the companion case of Vacco v. Quill,,$^{53}$ the United States Supreme Court upheld New York statutes that placed a ban on physician-assisted suicide. New York banned assisting suicide through two criminal statutes. The first is a manslaughter provision: "A person is guilty of manslaughter in the second degree when... (3) He intentionally causes or aids another person to commit suicide." ${ }^{54}$ The second is the "promoting a suicide attempt" provision: "A person is guilty of promoting a suicide attempt when he intentionally causes or aids another person to attempt suicide." 55

Under a Fourteenth Amendment Equal Protection analysis, the Court differentiated between assisted suicide and the voluntary refusal of life-sustaining

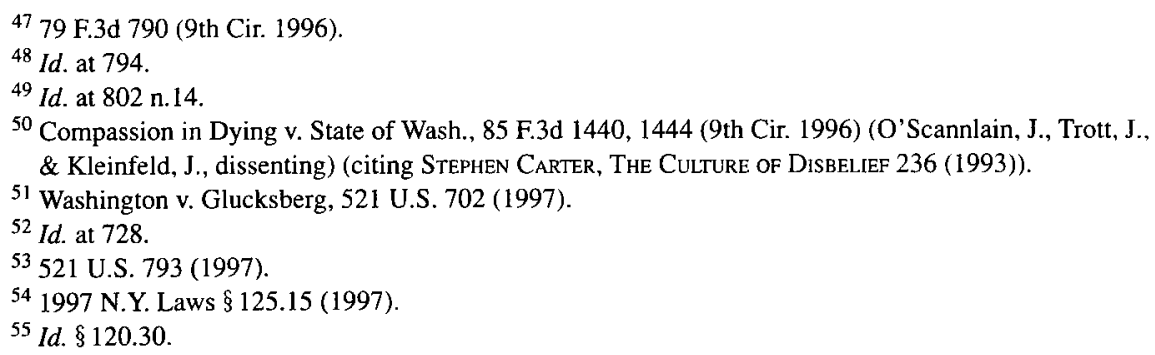


treatment. The Court found that a person who refuses treatment dies from natural, underlying causes. On the other hand, when a person opts for assisted suicide, it is an unnatural cause of death. ${ }^{56}$ The Court acknowledged the specific intent requirement for a criminal conviction. Accordingly, when a physician administers a potentially lethal dose of medication for pain, the specific intent is to alleviate pain. When a physician administers a lethal dose to assist in a suicide, the specific intent is to terminate life. The Court also analyzed specific intent requirements from the point of view of the patient. ${ }^{57}$ The patient who refuses treatment might not do so with the specific intent to die, but rather with the specific intent to live, only to do so free of medical treatments. On the other hand, when a patient opts for assisted suicide, the specific intent necessarily is a wish to die. ${ }^{58}$ The Court dismissed the importance of distinguishing between an act of refusal and an act of suicide as being "a meaningless exercise in semantic gymnastics." Essentially, the determination is one of public policy.

The Court ultimately held that the New York ban on assisted suicide is not a violation of the Equal Protection clause because it applies equally to all people and does not infringe on any fundamental rights. On the other hand, states could choose to authorize the practice with appropriate legislative action. ${ }^{60}$ In states like Hawaii with no statutory prohibitions such as those existing in New York and Washington, the legality of PAS and PAD is unclear.

\section{B. Jurisdictions that Authorize PAS and PAD}

Because there is no federal constitutional right to assisted suicide, the power to authorize the practice of PAS and PAD is reserved to the states. To date, Oregon is the only state that has statutorily authorized PAS and PAD. ${ }^{61}$ One foreign jurisdiction that has practices of PAS and PAD similar to those authorized in Oregon is the Netherlands. The experiences of both Oregon and the Netherlands were influential in the work of Hawaii's Blue Ribbon Committee on Living and Dying with Dignity. ${ }^{62}$ Because Hawaii almost became the second state to specifically authorize $\mathrm{PAS}^{63}$ and relied heavily on

\footnotetext{
56521 U.S. 793 (1997).

${ }^{57}$ Id. at 804 .

${ }^{58} \mathrm{Id}$.

${ }^{59} \mathrm{Id}$.

${ }^{60} \mathrm{Id}$. at 809.

${ }^{61}$ See Oregon Death with Dignity Act, Or. Rev. Stat. $\$ 127.800$ (2001). The state of Oregon had conducted a voter referendum on PAS in 1994, passing PAS by a vote of $51 \%$ to $49 \%$. Following the Supreme Court cases of Vacco and Glucksberg, a second Oregon referendum in November 1997 again passed PAS, but by an increased margin of $60 \%$ to $40 \%$.

${ }^{62}$ See, e.g., FinAl Report, supra note 1, at 25-26 \& Appendix M 23-24.

${ }^{63}$ The "Death with Dignity" Bill, H.B. 2487, 2002 Leg., 22nd Sess. (Haw. 2002), was introduced in the Hawaii legislature as S.B. 2745, 2002 Leg., 22nd Sess. (Haw. 2002) on January 24, 2002. It passed first reading and was referred to the Judiciary and Hawaiian Affairs Committees, which recommended that
} 
information about the Netherlands ${ }^{64}$ and Oregon, a basic understanding of the Oregon law and Dutch experience are relevant to this discussion.

\section{Oregon Death with Dignity Act}

The Oregon Death with Dignity Act provides that an adult who is capable ${ }^{65}$ a resident of Oregon, has been determined by the attending and consulting physician ${ }^{66}$ to be suffering from a terminal disease,${ }^{67}$ and has voluntarily expressed a wish to die, may make a written request ${ }^{68}$ for medication for the purpose of ending his or her life in a humane and dignified manner. ${ }^{69}$ If, in the opinion of the attending or consulting physician, a patient may be suffering from a psychiatric or psychological disorder or depression causing impaired judgment, either physician must refer the patient for counseling. No medication to end a patient's life in a humane and dignified manner may be prescribed until the person performing the counseling determines that the patient is not suffering from a psychiatric or psychological disorder or depression causing impaired judgment. ${ }^{70}$

To receive a prescription for medication to end life in a humane and dignified manner, a qualified patient must have made an oral request and a written request, and reiterate the oral request to the attending physician no less than 15 days after making the initial oral request. At the time the qualified patient makes a second oral request, the attending physician must offer the patient an opportunity to rescind the request. ${ }^{71}$ A patient may rescind a request at any time and in any manner without regard to his or her mental state. No prescription for medication may be written without the attending physician offering the qualified patient an opportunity to rescind the request. ${ }^{72}$ No less than 15 days shall elapse between the patient's initial oral request and the

the measure be passed with amendments. The measure later passed third reading. The bill crossed over to the Senate on March 8, 2002, and passed the first reading. The Committee on Health and Human Services deferred the measure, but it narrowly passed second reading (by a margin of 13 to 12) after it was recalled. The bill failed to pass third reading by a margin of 11 to 14 .

${ }^{64}$ See FINAL REPORT, supra note 1 , at 25.

${ }^{65}$ Or. Rev. STAT. $§ 127.800$ (3) (2001). "Capable" means that, in the opinion of a court or the patient's attending physician or consulting physician, psychiatrist, or psychologist, a patient has the ability to make and communicate health care decisions to health care providers, including communication through persons familiar with the patient's manner of communicating, if those persons are available.

${ }^{66} I d . \S 127.800$ (12). Before a patient is qualified under sections 127.800 to 127.897 , a consulting physician shall examine the patient and his or her relevant medical records and confirm, in writing, the attending physician's diagnosis that the patient is suffering from a terminal disease, and verify that the patient is capable, acting voluntarily, and has made an informed decision.

${ }^{67}$ Id. (defining "terminal disease" as "an incurable and irreversible disease that has been medically confirmed and will, within reasonable medical judgment, produce death within six (6) months").

68 Id. $\$ 127.897$.

69 Id. $\S 127.805$.

${ }^{70}$ Id. $\S 127.825$.

${ }^{71} I d . \S 127.840$.

72 ld. § 127.845. 
writing of a prescription. ${ }^{73}$ No less than 48 hours shall elapse between the patient's written request and the writing of a prescription. ${ }^{74}$

No health care provider is under any duty to provide to a qualified patient medication to end the patient's life. ${ }^{75}$ If a health care provider is unable or unwilling to carry out a patient's request and the patient transfers care to a new health care provider, then the prior health care provider must transfer, upon request, a copy of the patient's relevant medical records to the new health care provider. $^{76}$

To comply with the law, physicians must report to the Oregon Health Department all prescriptions for lethal medications. ${ }^{77}$ No person shall be subject to civil or criminal liability or professional disciplinary action for good faith compliance with the Act. This includes being present when a qualified patient takes the prescribed medication to end life. ${ }^{78}$

Nothing in the Act is to be construed to authorize a physician or any other person to end a patient's life by lethal injection, mercy killing, or active euthanasia. ${ }^{79}$ Actions taken in accordance with the Act do not for any purpose constitute suicide, assisted suicide, mercy killing, or homicide.

In its Fifth Annual Report on Oregon's Death with Dignity Act, the Oregon Department of Human Services' Office of Disease Prevention and Epidemiology characterized the 38 people who ingested legally prescribed lethal medications during 2002. ${ }^{80}$ The Report indicated the differences and similarities between the 2002 patients and those from prior years. ${ }^{81}$ In 2002 , a total of 33 physicians wrote 44 prescriptions for lethal doses of medication. By comparison, physicians wrote 44 prescriptions in 2001, 39 in 2000, 33 in 1999 , and 24 in $1998 .^{82}$ The number of deaths from lethal prescriptions also has increased over the past five years. The Report shows that there was a total of 38 deaths in 2002, 21 in 2001, 27 in 2000, 27 in 1999, and 16 in 1998. ${ }^{83}$

The 36 people who ingested lethal medications in 2002 represented $13 \%$ of the deaths in Oregon. ${ }^{84}$ This compares to $.07 \%$ in $2001, .09 \%$ for 2000 and 1999 , and only $.06 \%$ in 1998 . While statistics specific to 2002 are not available, between the years 1998 and 2002 the 129 patients who took lethal doses were

${ }^{73} I d . \S 127.840$.

${ }^{74}$ Id. $\$ 127.850$.

${ }^{75}$ Id. $\$ 127.885(4)$.

${ }^{76} \mathrm{Id}$.

${ }^{77}$ Or. Admin. R. 333-009-000 to 333-009-0030.

${ }^{78}$ Or. Rev. Stat. § 127.885 (1999).

${ }^{79}$ Id. $\$ 127.880$.

80 Oregon Department of Human Services, Office of Disease Prevention and Efidemiology, Fifth Annual Report on Oregon's Death with Dignity Act (Katrina Hedberg et al. eds. Mar. 6, 2003). Although 38 people died in 2002, two of them received their prescriptions in 2001.

${ }^{81} \mathrm{Id}$.

${ }^{82}$ Id. at 11 .

${ }^{83} \mathrm{Id}$.

${ }^{84} I d$. 
different from the 42,274 other Oregonians who died of the same underlying disorders. Patients who opted for the lethal prescriptions were more likely to be younger, Asian, divorced, well-educated, and suffering from either cancer or amyotrophic lateral sclerosis. ${ }^{85}$ Statistics indicate that the patients in 2002 were comparable to those of the past, but had a higher representation of males and people without college degrees. ${ }^{86}$ Cancer, as in prior years, was the most common underlying illness. The three most commonly mentioned end-of-life concerns in 2002 were loss of autonomy, a decreasing ability to participate in activities that made life enjoyable, and losing control of bodily functions. ${ }^{87}$

The lethal medications ingested during 2002 differed from those used in previous years. Between 1998 and 2001, the majority ( 83 of 91 ) of patients received secobarbital. When Eli Lilly stopped producing that drug, physicians began to prescribe pentobarbital and Tuinal. In 2002, only two patients used secobarbital, two used Tuinal, and others used pentobarbital. Two patients in 2002 had complications with the medication. The first patient gagged for 10-15 seconds and coughed up clear mucoid material and the other patient vomited. ${ }^{88}$ Both patients died within two hours. After taking the medication, no patient regained consciousness, and none lived longer than 14 hours. ${ }^{89} \mathrm{Al}-$ though the number of prescriptions written for physician-assisted suicide has increased since 1999 , the number of terminally ill patients ingesting lethal medications has remained small, with less than one-eighth of $1 \%$ of Oregonians dying by PAS. ${ }^{90}$

In 2001 , only $13 \%$ of referrals for assisted suicide had earlier received recommendations for palliative care consultation. ${ }^{91}$ Although this statistic was the inspiration for much criticism, ${ }^{92}$ the 2002 Report indicates that "the availability of PAS may have led to efforts to improve end-of-life care through other modalities .... [A] request for PAS can be an opportunity for a medical provider to explore with patients their fears and wishes around end-of-life care ... ."933 Further, the Fifth Annual Report indicates that physicians have "made efforts to improve their knowledge of the use of pain medications in the terminally-ill, to improve their recognition of psychiatric disorders such as depression, and to refer patients more frequently to hospice." 94

85 Id. at $11-12$.

${ }^{86} \mathrm{Id}$. at 11 .

${ }^{87}$ Id. at Table 3.

${ }^{88} \mathrm{Id}$. at 13 .

${ }^{89} \mathrm{Id}$. The patient who lived for 14 hours suffered from a completely obstructed bowel.

${ }^{90}$ Id. at 14.

91 Oregon Department of Human Services, Office of Disease Prevention and Epidemiology, Fourth AnNual. Report on Oregon's Death with Dignity Act (Feb. 6, 2002).

92 See, e.g., Herbert Hendin \& Kathleen Foley, Teach Options to Assisted Suicide Instead, Honolulu AdVERTISER, Feb. 9, 2003, available at http://the.honoluluadvertiser.com/article/2003/Feb/09/op/ op13a.html

${ }^{93}$ REPORT, supra note 80 , at 15 .

${ }^{94}$ Id. 
In its Sixth Annual Report, the Oregon Department of Human Services' Office of Disease Prevention and Epidemiology characterized the 42 people who ingested legally prescribed lethal medications during $2003 .{ }^{95}$ The 2003 report does not seem to contain any significant differences from the first five reports. The number of individuals who ingested prescribed lethal medications has increased slightly, but the overall number has remained small, with about $1 / 7$ of $1 \%$ of Oregonians dying by physician-assisted suicide. ${ }^{96}$

In 2003, 42 physicians wrote a total of 67 prescriptions for lethal doses of medication. The number of prescriptions written increased in each of the previous years: 58 prescriptions were written in 2002; 44 in 2001; 39 in 2000; 33 in 1999; and 24 in 1998. Thirty-nine of the 2003 prescription recipients died after ingesting the medication. Of the 28 persons who did not ingest the prescribed medication, 18 died from their illnesses, and 10 were alive on December 31, 2003. In addition, two patients who received prescriptions during 2002 and another who received a prescription in 2001 died in 2003 after ingesting their medications, for a total of 42 PAS deaths during 2003. ${ }^{97}$

With regard to the legally authorized lethal medications utilized during 2003, 37 patients (88\%) used pentobarbital, four patients used secobarbital, and one used secobarbital/amobarbital. Since the Death with Dignity Act was implemented, 52\% of the PAS patients used secobarbital, $46 \%$ used pentobarbital, and $2 \%$ used other medications (mostly secobarbital/ amobarbital). ${ }^{98}$

As suggested by Hawaii proponents of PAS legislation, ${ }^{99}$ the availability of PAS in Oregon may have led to efforts to improve end-of-life. The 2004 Oregon Report indicated that, while it may be common for patients with a terminal illness to consider PAS, a request for PAS can be an opportunity for a medical provider to explore with patients their fears and wishes around end-of-life care and to make patients aware of other options. ${ }^{100}$ The Report further indicates that the availability of PAS as an option in Oregon also may have spurred Oregon physicians to address other end-of-life care options more effectively. ${ }^{101}$

\footnotetext{
95 Oregon Department of Human Services, Office of Disease Prevention and Epidemiology, Sixth Annual Report on Oregon's Death with Dignity ACt (Richard Leman ed. Mar. 10, 2004).

${ }^{96} I d$. at 5.

${ }^{97}$ Id. at 11 .

${ }^{98} \mathrm{Id}$. at 13 .

${ }^{99}$ See, e.g., Roland L. Halpern, Don't Despair over Bill's Rejection, Letter to the Editor, HonoluLu ADVERTISER, Mar. 12, 2004, at A17.

${ }^{100}$ REPORT, supra note 80 , at $15-16$.

${ }^{101}$ Id. at 16 . The Report states that, in one study, Oregon physicians reported that, since passage of the Death with Dignity Act in 1994, they had made efforts to improve their knowledge of the use of pain medications in the terminally ill, to improve their recognition of psychiatric disorders such as depression, and to refer patients more frequently to hospice.
} 


\section{The Dutch Experience}

The practice of euthanasia in the Netherlands is defined as "the termination of life by a doctor at the request of a terminally ill patient.". 102 To be legal, the goal of this practice must be to end unbearable suffering and it must derive from the voluntary request of the patient. Euthanasia is distinguishable from withholding medication, opting against futile treatment, or administering pain medication at a lethal dose.

Physicians have no obligation to comply with the requests of patients and are shielded from liability for refusing to comply. On the other hand, a physician who refuses to comply with a request must refer the patient to a provider who will comply. ${ }^{103}$

Even if a request is accepted, a physician still must determine that the patient is terminally ill. Next, a physician must assess the mental and physical disposition of the patient and obtain a second opinion from another physician. The joint opinion of the two physicians must have a firm medical basis and conform to accepted rules of medical ethics. ${ }^{104}$

When carrying out a patient's request for euthanasia, a Dutch physician is bound by a statutory duty of due care. This duty requires the physician to confidently assert that the patient's request is voluntary and well-considered. Further, patients must be free of undue influence and able to understand the nature of their condition and the prospects and types of available treatment. A patient also must repeatedly express the wish to die.

Having determined that these prerequisites have been met, a physician then must be satisfied that the patient's suffering is unbearable and the condition is terminal. If the patient meets these qualifications, then the physician must inform the patient of the prognosis and discuss the condition with the patient, and they must mutually conclude that there is no reasonable alternative to euthanasia. An independent physician then must state in writing that the attending physician has acted with due care. Ultimately, only the attending physician may administer the lethal dose and then must remain with or near the patient until death occurs. ${ }^{105}$

Following the death of the patient, the physician must notify the municipal pathologist. The pathologist performs an autopsy to determine that the procedure was performed appropriately and reports the findings to a review committee. ${ }^{106}$ The review committee reviews reports of both the physician and the medical examiner, including any annexes such as health care directives. The committee consists of a legal expert, physician, and expert on ethics. Each member is appointed for a six-year term. It is the committee's responsibility

\footnotetext{
102 See Netherlands Criminal Code, Termination of Life on Request and Assisted Suicide Act (2002). ${ }^{103} \mathrm{Id}$.

104 Id.

$105 \mathrm{Id}$.

${ }^{106} \mathrm{Id}$.
} 
to determine whether the attending physician should be subject to criminal prosecution under the Criminal Code. ${ }^{107}$

The Criminal Code provides that the acts of people who assist suicide inappropriately are punishable by up to 12 years in jail or a fine. Further, counseling a person to commit suicide is punishable by up to three years in prison. Physicians are immune from prosecution if they meet all the statutory requirements. ${ }^{108}$

The Netherlands permits a minor between ages 12 and 15 to request euthanasia with the consent of a parent or guardian. Minors between ages 16 and 17 can make a request; a parent or guardian must be consulted, but need not consent. People with cognitive disorders such as dementia may not request euthanasia unless they have an advance directive, executed while the person was still competent, that requests it. Foreign patients are not permitted to come to the Netherlands for the purpose of obtaining euthanasia.

\section{Other Laws on Assisted Death}

The Euthanasia Research and Guidance Organization (ERGO) ${ }^{109}$ reports that only four places in the world openly practice assisted death. They include, in addition to Oregon and the Netherlands, the European nations of Switzerland and Belgium. Generally, each of these countries imposes similar regulations as those described above for Oregon. ERGO also reports that a high court in Japan has approved medical voluntary euthanasia. ${ }^{110}$ Given the influence of the Japanese culture in Hawaii, this may be a significant point of interest.

\section{PAS and PAD in Hawaii}

Hawaii has no clear statutory authority authorizing PAS and PAD such as exists in Oregon, but neither does it have any clear prohibitions relating to PAS and PAD such as those existing in New York and Washington. Accordingly, the law in Hawaii is unclear.

\section{Analysis of Hawaii Laws Relating to PAD/PAS}

Sometimes the distinction between not wanting to live and wanting to actively kill oneself is not very clear. ${ }^{111}$ Under previous Hawaii law, the state

\footnotetext{
${ }^{107} \mathrm{Id}$.

${ }^{108} \mathrm{Id}$.

${ }^{109}$ Euthanasia Research \& Guidance Org., World Laws on Assisted Suicide, available at http://www. finalexit.org/worldlaws.html (last visited Dec. 17, 2003). The Euthanasia Research \& Guidance Organization (ERGO) describes itself as "a nonprofit educational corporation that promotes research on assisted dying for terminally or hopelessly ill people who wish to end their suffering."

${ }^{110} I d$. ERGO reports that Japan approved medical voluntary euthanasia in the 1962 High Court case of Yamagouchi, but that the practice remains extremely rare because of social and cultural beliefs and values.

111 See James Pietsch \& Lenora Lee, The Elder Law Hawail Handbook (1998). Much has been written about "rational suicide" and maintaining control over one's life even in the face of devastating physical
} 
did not condone, authorize, or approve of mercy killing or euthanasia. ${ }^{112}$ In 1999, the UHCDA replaced this law. The resulting provision regarding PAD is more neutral. ${ }^{113}$ A basic question is whether assisted suicide is prohibited by other statutes in Hawaii.

There are clear guidelines and protections under Hawaii's UHCDA for an individual who decides to have life-sustaining medical treatment withheld or withdrawn:

Death resulting from the withholding or withdrawal of healthcare in accordance with this chapter shall not for any purpose constitute a suicide or homicide or legally impair or invalidate a policy of insurance or an annuity providing a death benefit, notwithstanding any term of the policy or annuity to the contrary. ${ }^{14}$

Although there is no law against suicide, the Hawaii Penal Code has been interpreted to prohibit physicians from assisting in suicides or otherwise helping to cause a death. ${ }^{115}$ Other prohibitions against PAS may derive from the common law. However, Hawaii has never prosecuted a physician, or anyone else, for causing or assisting a suicide. ${ }^{116}$ The salient issue is whether a physician who assists a patient to die by providing a lethal agent commits the offense of manslaughter by intentionally causing another person to commit suicide.

As in other jurisdictions, Hawaii law often treats the subject of suicide in the context of mental illness. For example, Hawaii law provides, in part,

illness or mental deterioration. Many people who would want their physician to assist them in their dying will not consider requesting a physician to assist them to commit suicide. For many, assisted suicide goes far beyond requesting that medical treatment be withheld or withdrawn and that pain medications be provided even if the administration of medication should have the "double effect" of hastening death. Others, in contrast, feel they have a right to request PAS. This subject brings up difficult issues of euthanasia, mercy killing, and, in general, the "right to die."

112 See Haw. Rev. Stat. \$ 327D-131 (1999) (repealed).

113 Haw. Rev. Stat. §327E-13 (1999).

(b) Death resulting from the withholding or withdrawal of healthcare in accordance with this chapter shall not for any purpose constitute a suicide or homicide or legally impair or invalidate a policy of insurance or an annuity providing a death benefit, notwithstanding any term of the policy or annuity to the contrary.

(c) This chapter shall not authorize mercy killing, assisted suicide, euthanasia, or the provision, withholding, or withdrawal of healthcare, to the extent prohibited by other statutes of this State.

${ }^{114}$ Id. $\S 327 \mathrm{E}-13$ (1999).

115 See id. $\$ 707-702$. This section states in part: "A person commits the offense of manslaughter if ... (h)e intentionally causes another person to commit suicide." The FINAL REPORT, supra note 1, at 24 \& 49 referred to the provision as the basis for concluding that PAS and PAD are illegal. However, in the author's conversation with the City and County of Honolulu Prosecutor's Office, it was apparent that the issue is not clear. Personal communications with Peter Carlisle, City and County of Honolulu Prosecutor's Office, Jan. 2003 \& Feb. 26, 2004.

${ }^{116}$ Multiple searches in 2002, 2003, and 2004 on Westlaw.com produced no Hawaii cases prosecuting anyone for assisting suicide under HAw. REv. STAT. \$707-702 (2003). 
that if a person is believed to be mentally ill or suffering from substance abuse and is imminently dangerous to self or others, that person may be subjected to involuntary emergency examination and hospitalization. ${ }^{17}$ There also are provisions that justify the use of physical force to prevent another from attempting suicide under specific circumstances. ${ }^{318}$ Finally, the penal code addresses suicide by requiring coroners to report the death of an individual if it appears that suicide is the cause. The penalty for failing to report such a death is a fine of $\$ 100 .^{119}$

Hawaii's Constitution incorporates an explicit privacy provision, which states: "The right of the people to privacy is recognized and shall not be infringed without the showing of a compelling state interest." ${ }^{20}$ This section guarantees a right to privacy that protects an individual's interest in avoiding disclosure of personal matters and in freely making certain important personal decisions. ${ }^{121}$ In the context of health care decision making, this provision has been cited as a basis for upholding the right of a person (or a guardian for an incompetent person) to refuse unwanted medical treatment. ${ }^{122}$

Perhaps the most unique and perplexing provision within Hawaii law is Hawaii Revised Statute section 453-1, which defines the practice of medicine. This statute provides:

\begin{abstract}
[W]hen a duly licensed physician pronounces a person affected with any disease hopeless and beyond recovery and gives a written certificate to that effect to the person affected or the person's attendant nothing herein shall forbid any person from giving or furnishing any remedial agent or measure when so requested by or on behalf of the affected person. ${ }^{123}$
\end{abstract}

Arguably, this provision could provide the authorization for physicians to actively assist a patient in dying by providing a lethal dose of medication under certain circumstances. A pertinent part of another statutory provision, however, reads: "This chapter shall not authorize mercy killing, assisted suicide, euthanasia, or the provision, withholding, or withdrawal of health care, to the extent prohibited by other statutes of this State."124 Although this is not an explicit prohibition of PAS, two key provisions require further inquiry.

The first key provision is in section 453-1, which includes two crucial phrases: "for the purposes of this chapter" and "nothing herein." Read in

\footnotetext{
${ }^{117}$ Haw. Rev. Stat. §334-59 (1997).

118 Id. $\$ 703-308$ (1993).

${ }^{119}$ ld. $\$ 841-3$ (1984).

${ }^{120}$ Haw. Const. art. I, $\S 6$.

${ }^{121}$ See, e.g., Doe v. City and County of Honolulu, 816 P.2d 306 (Haw. 1991).

122 In re Guardianship of Crabtree, No. 86-0031 (Haw. Fam. Ct., 1st Cir. Apr. 26, 1990).

${ }^{123}$ Haw. Rev. Stat. §453-1 (1984).

${ }^{124}$ Id. $§ 327 \mathrm{E}-13$ (c).
} 
combination and without regard to other provisions of the law, these phrases do not seem to prohibit physicians from assisting in suicide under certain circumstances, and may even authorize the practice. The question is whether this language applies only to chapter 453, "Medicine and Surgery," or to the Revised Statutes as a whole. Absent any evidence of the legislative intent, there is no way to determine this basically unexamined point of law. ${ }^{125}$ On the other hand, even if the language is intended to be inclusive, when read in conjunction with the UHCDA there still appears to be no explicit prohibition of PAS when the second key phrase is examined.

The second key phrase is the reference to "other statutes" in section 327E-13(c) of the UHCDA. The question is whether other Hawaii statutes prohibit PAS in particular, or even assisted suicide in general. The manslaughter law prohibits "intentionally causing" another person to commit suicide. ${ }^{126}$ It is the only statute that actually places a prohibition on actions relating to suicide. The ultimate question is whether "causing" suicide is the same as "assisting" suicide. Convicting a physician under this statute may be difficult.

In an interview, the City and County of Honolulu Prosecutor's Office indicated to the author that it might attempt to prosecute PAS under the manslaughter prohibition of section 707-702. ${ }^{127}$ If it were to do so, the Prosecutors' Office would base its case on a theory that the physician acted "recklessly." 28 Such a case likely would turn on application of the "subjective/objective rule of criminal liability."129 Under this rule, the trier of fact "would determine whether the defendant appreciated the wrongfulness of his conduct from the point of view of a reasonable person in the defendant's position under the circumstances as he believed them to be." 130

This theoretical approach to the manslaughter provision is untested and, accordingly, uncertain. Numerous questions exist. For example, an issue arises if the physician uses section 453-1 as a justification and affirmatively claims to have acted "intentionally" or "knowingly." 131 Due to the law's ambiguity,

\footnotetext{
125 Personal communication with the City and County of Honolulu Prosecutor's Office (Jan. 2003).

${ }^{126}$ Haw. Rev. STAT. $\$ 707-703(1)$ (b) (1988).

${ }^{127}$ Personal communication with the City and County of Honolulu Prosecutor's Office (Jan. 2003).

${ }^{128}$ Haw. Rev. Stat. $\$ 702-206$ (1986).

${ }^{129}$ See, e.g., State v. Sawyer, 966 P.2d 637, 645 (Haw. 1988) (" "[T]he defendant must satisfy a subjective/objective test' in proffering a 'reasonable explanation' in accordance with HRS § 707-702(2). First, in satisfying the subjective portion, the record must reflect the circumstances as the defendant believed them to be. Second, in satisfying the objective portion, the record must support 'a reasonable explanation or excuse for the actor's disturbance.' ") See also State v. Kaiama, 911 P.2d 735, 746 (Haw. 1996) ("To satisfy the second prong of HRS $\S 707-702(2)$, i.e., a reasonable explanation, the defendant must satisfy a subjective/objective test. The circumstances must be viewed as the defendant believed them to be (subjective); however, [t]he ultimate test is objective[.] [T] here must be a reasonable explanation or excuse for the actor's disturbance.") (citations omitted); State v. Pemberton, 796 P.2d 80, 85 (Haw. 1990).

${ }^{130}$ State v. Uyesugi, 60 P.3d 843 (Haw. 2002) (interpreting Haw. Rev. Stat. $§ 707-702$ ).

${ }^{131}$ See Haw. Rev. STat, $\$ 702-206$ (1986) (defining states of mind).
} 
it certainly might be possible for a defendant to pass the subjective/objective test. ${ }^{132}$ The defendant may not believe the acts were wrongful and a reasonable person in the defendant's position might agree. Further, as has been the experience in Oregon, it is possible that the patient would not die as a result of the medication. In that instance, the crime at most would be "attempted manslaughter." Such an offense is not recognized under the Hawaii Penal Code, nor is it a part of the common law. ${ }^{133}$ In sum, successfully prosecuting physicians under the statutory manslaughter provisions and recklessness standards would be difficult at best. Using section 453-1 as a justification may create a unique barrier to the prosecution of PAD.

No other state has a statute similar to section 453-1. On its face, it seems to authorize a physician to assist suicide, but perhaps not to "intentionally cause" suicide. This interpretation draws a fine line. A common-law analysis may prove as constrained. The Westlaw Research References for this Hawaii statute cite to an entry in the American Law Reports. ${ }^{134}$ Although that cited article may demonstrate that physicians could be held liable for not preventing a suicide, it may not be persuasive in Hawaii courts because it does not cite any Hawaii cases and seems to focus on physicians' duties to mentally ill patients, a topic that would not necessarily apply under section $453-1$. That article also discusses several cases in which physicians were held immune from liability based on "official or discretionary acts under state statutes." 135 That analysis, combined with the explicit language of the statute providing protection to a physician when "giving or furnishing any remedial agent or measure when so requested by or on behalf of the affected person," may provide a sufficient basis for physicians in Hawaii to evade common-law responsibility. One of the most compelling reasons to believe that the penal code may not apply to PAS or PAD is that the Honolulu Prosecutor's Office has stated that section 453-1 would need to be changed if legislative attempts to authorize PAS or PAD are successful. ${ }^{136}$

Although existing laws in Hawaii do not provide a clear answer about whether PAS and PAD are illegal or authorized, the legislature has the ability to decide and clarify the issue. Past legislative initiatives have found their genesis in investigative and advisory boards such as Hawaii's Blue Ribbon Panel on Living and Dying with Dignity.

\footnotetext{
${ }^{132}$ See Kaiama, 911 P.2d at 746 . To overcome the subjective prong, arguably it would only be necessary for a physician to show that the record reflected that the events were as the physician believed them to be. To overcome the objective prong, arguably it would only be necessary for a physician to show that the record reflected that there was a reasonable explanation or excuse for the action.

${ }^{133}$ See generally State v. Holbron, 904 P.2d 912 (Haw. 1995) (holding that "there can be no offense of 'attempted manslaughter' within the meaning of HRS $\$ 707-702(1)(a) ")$.

1348 A.L.R.4TH 464, superseded by Patricia C. Kussman, Liability of Doctor, Psychiatrist, or Psychologist for Failure to Take Steps to Prevent Patient's Suicide, 81 A.L.R.5TH 167 (2000).

${ }^{135}$ Id. $\$ 16$.

${ }^{136}$ Personal communication, supra note 125.
} 


\section{Hawaii's Blue Ribbon Panel on Living and Dying with Dignity}

In 1997, Governor Benjamin Cayetano established a Blue Ribbon Panel on Living and Dying with Dignity to explore this issue in Hawaii. On June 8, 1998, the Blue Ribbon Panel presented its final report. ${ }^{177}$ The panel reached unanimous agreement on six major areas affecting most of the 8,000 deaths that occur in Hawaii every year. Panel members differed only on PAS and PAD, which, if legalized, would affect relatively few deaths, probably no more than 300 persons per year.

The Blue Ribbon Panel was unanimous on the following points:

1. Spiritual counseling should be made more available to individuals who are afflicted with life threatening illnesses by integrating those services more fully into the health care system;

2. Public and health care professional education programs should be designed and implemented to increase awareness of the choices available to the dying;

3. The content of advance directives for health care, including "living wills," should be made more specific, their use more widespread, and their provisions more binding;

4. Hospice care should be made more available and offered more expediently to the dying;

5. Effective pain management programs should be required in all health care institutions;

6. Involuntary euthanasia should continue to be a crime. ${ }^{138}$

The Blue Ribbon Panel was split on the issue of PAD. Eleven panel members voted to recommend the legalization, under strict controls, of PAS in which a physician gives a prescription to be taken by a patient and PAD in which the physician could cause death by injection at the patient's request. Patients would have to be terminally ill or suffer intractable or unbearable pain that cannot be cured or successfully palliated before either of these methods could be made available. ${ }^{139}$ Required safeguards would include an explicit written request from the patient, a two-week waiting period at the end of which the patient must reaffirm his or her decision explicitly, the consultation of a second physician, psychiatric consultation, and a social work and/or pain management consultation. ${ }^{140}$

In describing its approach to the question of PAS and PAD, the Blue Ribbon Panel noted:

These are societal matters too important for any one profession to shoulder, and which must be brought out into the open and addressed by the best efforts of the society.

Our respect for individual's [sic] rights of self-determination brings us to the view that requests for assistance with dying should be taken seriously. The major concern

\footnotetext{
${ }^{137}$ FinAl REPORT, supra note 1.

138 Id. at 5 .

${ }^{139}$ Id. at 29 \& Appendix F 54.

${ }^{140} I d$. at 30 \& Appendix F 53.
} 
is whether such requests are made by competent patients who have been offered all the services available to address their situation.

Great care must be taken to ensure that a decision follows a full exploration of other options which may ameliorate the grounds for the request.

But when all avenues and methods of assistance have been exhausted or unsuccessful and the patient with a terminal condition or intractable and unbearable suffering persists in his or her request for assistance in dying, that request must not be refused lightly.

We believe that in Hawaii especially, it is important that no one perspective be allowed to impose its beliefs and mores on another. We have concluded that individuals who have no compunction regarding physician-assisted dying should be allowed to follow the dictates of their conscience. ${ }^{141}$

Seven members voted against the recommendation or abstained. Several members submitted dissenting reports, with differing reasons for opposition to the recommendation or for not voting in favor of the recommendation.

\section{HAWAII LEGISLATIVE PROPOSALS ON PHYSICIAN-AID-IN-DYING}

Over the past few years, several bills have been introduced in the Hawaii legislature that would have legalized PAS and PAD. Hawaii nearly passed a bill that would have permitted physician-aid-in-dying in the 2002 legislative session. The bill changed dramatically from its original form during the course of the session. The evolution of the bill demonstrates how Hawaii is attempting to manage the issue of physician-aid-in-dying.

\section{A. The Original Bill}

The purpose of the original version of HB 2487 (2002) was to provide, in certain circumstances, for the administration of death with dignity to persons who request it and are suffering from a terminal condition, and to enable persons to request in advance the administration of "death with dignity" in the event of their suffering from such a condition at a future date. ${ }^{142}$ The bill provided that physicians could administer "death with dignity" to qualified patients who were in a terminal condition. Unlike the Oregon Act, this proposed bill translated the concept of death with dignity into a specific action. In the definitions section, "death with dignity" meant the painless inducement of death. ${ }^{143}$ Notwithstanding any other law to the contrary and subject to other provisions of the bill, it would have been lawful for a physician to administer death with dignity to a qualified patient who had made a declaration that was

\footnotetext{
141 Id. at $27-28$.

${ }^{142}$ H.B. $2487, \S 2$ (2002).

${ }^{143}$ Id. $\S 3$.
} 
in force at the time. ${ }^{144} \mathrm{~A}$ qualified patient with a declaration, suffering from a terminal condition, would have been entitled to the administration of whatever quantity of drugs would be required to keep the patient free from pain. A patient whose severe distress could not otherwise be relieved would have been entitled to drugs rendering the patient continuously unconscious if the patient so requested.

There would have been certain protections. For example, before administering "death with dignity" to a qualified patient, the physician in charge would have had to ascertain with reasonable satisfaction that the declaration and all steps proposed to be taken under it accorded with the patient's wishes. ${ }^{145}$ Although the bill stressed the role of the physician, others also might have been involved. For example, "death with dignity" measures by a physician could have been administered by a registered nurse. ${ }^{146}$ The bill would not have required participation. No person would have been under any duty, whether by contract or any statutory or other legal requirement, to participate in any treatment to which the person had a conscientious objection. ${ }^{147}$ There would have been protections for health care providers. A physician or nurse who, acting in good faith, administered "death with dignity" to a qualified patient in accordance with the bill and with what the actor believed to be the patient's declaration and wishes, would not have been subject to any civil liability and would not have been guilty of any criminal offense. ${ }^{148}$ Further, physicians and nurses who took part in the administration of "death with dignity" in accordance with this bill would have been deemed not to be in breach of any professional oath or affirmation. ${ }^{149}$ The bill would have amended Hawaii's UHCDA to conform that statute to the new chapter.

\section{B. The Modified Bill}

The language of the bill changed over the course of the 2002 legislative session. The final bill brought to the floor of the legislature was House Bill 2487, House Draft $1 .^{150}$ To better protect patients against abuse, the bill was amended to closely track the Oregon Death with Dignity Act. The amended measure required that a person be 18 years or older, a resident of the state of Hawaii, diagnosed with a terminal illness leading to death within six months, and able to make and communicate health care decisions.

\footnotetext{
${ }^{144} I d . \S 4$.

${ }^{145}$ Id. $\S 8(\mathrm{a})$.

${ }^{146}$ Id. $\$ 8(\mathrm{~b})$.

${ }^{147} I d . \$ 8(\mathrm{c})$.

${ }^{148}$ Id. $\$ 9$ (a).

${ }^{149}$ Id. $\$ 9(\mathrm{~b})$.

${ }^{150}$ H.B. 2487 H.D.1, 2002 Leg., 22nd Sess. (Haw. 2002).
} 
On meeting those requirements, the patient would have been eligible to request a prescription for medication from a licensed Hawaii physician on meeting several procedural criteria:

1. Two oral requests would have to be made by the patient to the physician, separated by at least 15 days;

2. A written request would have to be made to the physician witnessed by two individuals, of which one is not any of the following:

(a) A family member,

(b) A beneficiary of the patient's estate,

(c) An owner, operator or employee of the treating medical facility, or

(d) A primary caregiver.

A third witness would be required and designated by the long term care facility if the patient was in such a facility at the time of the written request;

3. The patient could rescind the request at any time;

4. The diagnosis and prognosis would have to be confirmed by the prescribing physician and a consulting physician;

5. The prescribing physician and a consulting physician would have to concur that the patient was capable to make a decision;

6. If either physician determined that the patient's judgment was impaired, the patient would have to be referred for a psychological examination;

7. The prescribing physician would be required to inform the patient of alternatives, including palliative care, hospice, and pain management options; and

8. The prescribing physician would have been required to recommend that the patient notify next-of-kin of the prescription request.

Furthermore, the bill required that physicians report to the state Department of Health all prescriptions for medication, and afforded protection from criminal prosecution to all physicians and patients complying with the bill. Additionally, the choice of legal PAD would not have affected the status of a patient's health or life insurance policies, and physicians and health care systems would not have been obligated to participate. ${ }^{151}$

${ }^{151} I d$. 
The legislative committee indicated that its support of this measure was in no way intended to detract from improvements in health care, hospice care, and public and professional education concerning pain management. ${ }^{152}$ The committee received testimony that, in Oregon, hospice care and pain management efforts increased and improved rather than diminished following implementation of legislation similar to the proposed Hawaii measure. ${ }^{153}$

Much like the Oregon Act, Hawaii's HB 2487 explicitly provided that nothing in the proposed legislation should be interpreted to authorize a physician or any other person to end a patient's life by lethal injection, mercy killing, or active euthanasia. Accordingly, the legislative committee found that the fear of euthanizing the frail and helpless of society was unfounded and that most people would take comfort in knowing that the PAS option was available to terminally ill patients. ${ }^{154}$ After considering public testimony, the 2002 legislature nearly enacted the measure. The measure was passed 30-20 by the House of Representatives on March 7, 2002 and came to the Senate floor for debate on May 2, 2002. The measure failed to pass in the Senate by three votes, 11-14.

\section{Subsequent Developments}

Since 2002, Compassion in Dying of Hawaii, a branch of a national advocacy group that became famous in Washington $v$. Glucksberg ${ }^{155}$ pressed the Hawaii legislature to pass a new death with dignity law. Specifically, Compassion in Dying of Hawaii in 2003 proposed House Bill 862 and companion Senate Bill 391, ${ }^{156}$ which in its Abstract states that the bill "allows a terminally ill, competent adult to get lethal dose of medication to end life, prohibits mercy killings, lethal injections, and active euthanasia, requires informed consent, allows alternate doctor to replace attending doctor if latter declines to prescribe, requires a monitor at the time of taking the lethal dose."157 The bill, like the 2002 legislative attempt, was substantially based on the Oregon Death with Dignity Act, which Compassion in Dying of Hawaii viewed as "extremely comprehensive" and successful in that it "has survived five years of scrutiny without any evidence of abuse." ${ }^{158}$ Although the 2002 session bill ${ }^{159}$

\footnotetext{
152 See Stand. Comm. Rep. No. 539-02 (Haw. Comm. on Judiciary and Hawaiian Aff. 2002).

${ }^{153} \mathrm{Id}$.

${ }^{154} \mathrm{Id}$.

${ }^{155}$ Washington v. Glucksberg, 521 U.S. 702 (1997).

${ }^{156}$ H.B. 862, 2003 Leg., 23rd Sess. (Haw. 2003).

${ }^{157}$ Id. at Abstract.

${ }^{158}$ Correspondence with Roland Halpern, Executive Director of Compassion in Dying, at 3 (Nov. 27 , 2002) (copy on file with author).

${ }^{159}$ H.B. 2749 (Haw. 2002).
} 
was rejected, House Bill 862 and companion Senate Bill $391^{160}$ were considered again in 2004. ${ }^{161}$

During the 2004 session, more than 150 people spoke before the House Judiciary Committee or submitted written testimony, which underscored the divided opinions even within the health care community and religious organizations. Those who supported the bill said terminally ill patients should have the ability to choose how they die and that the proposed law had safeguards against abuse. Opponents said allowing physician-assisted suicide would make patients feel they have an obligation to die and would hinder efforts to improve end-of-life care. The committee approved the bill by a 10-5 vote and sent it to the full House. ${ }^{162}$ In the end, however, the latest efforts also failed, apparently because the legislature was uncomfortable in taking up the issue in an election year. ${ }^{163}$

\section{Pain Patient's Bill of Rights}

The controversy over PAS and PAD may indeed have spurred greater interest in palliative care. ${ }^{164}$ The 2004 legislature considered and passed another bill carried over from the 2003 session, the "Pain Patient's Bill of Rights," which authorizes physicians to prescribe medically necessary doses of controlled substances to treat intractable pain and protect physicians from disciplinary action when doing so. ${ }^{165}$ This is a separate issue from PAS and PAD, but it is indicative of the concern over pain at the end of life.

${ }^{160}$ H.B. 862, 2003 Leg., 23rd Sess. (Haw. 2003). However, in an interesting twist on the issues presented in this article, the bill stated:

Nothing in this section shall be construed to...prohibit the discipline or prosecution of a licensed physician for ... causing, or assisting in causing, the suicide, euthanasia, or mercy killing of any individual; provided that it is not "causing, or assisting in causing, the suicide, euthanasia, or mercy killing of any individual" to prescribe, dispense, or administer medical treatment for the purpose of treating severe chronic intractable pain, even if the medical treatment may increase the risk of death, so long as the medical treatment is not also furnished for the purpose of causing, or the purpose of assisting in causing, death for any reason.

161 The bills were rejected during the 2003 session. Because the Hawaii legislature operates on a two-year basis, the bill was still alive for the 2004 session.

162 Lynda Arakawa, Bill on Assisted Suicide Advances, HonOlulu Advertiser, Mar. 5, 2004, available at http://the.honoluluadvertiser.com/article/2004/Mar/05/ln/ln05a.html

163 Gordon Pang \& Lynda Arakawa, "Death with Dignity" Bill Shelved, Honolulu AdverTiser, Mar. 10, 2004 , at B1.

164 See supra text accompanying note 98.

${ }^{165}$ H.B. 1839, 2004 Leg., 23rd Sess. (Haw. 2004). The bill authorizes prescribing medically necessary controlled substances to treat severe acute or chronic pain, allows physicians to refuse to prescribe but refer patients to physicians who use opiates for pain management and authorizes the Board of Medical Examiners to establish pain management guidelines. 


\section{CONCLUSION}

The judicial, legislative, executive, and private sectors have been poised to participate in an effort to improve the dying process in Hawaii. It now may be time to bring together the concepts of informed consent, patient autonomy, and self-determination and analyze them through the lens of the Governor's Blue Ribbon Panel's recommendations and the United States Supreme Court's "green light" for each of the states to decide the issue of PAD. Perhaps the vision will be to proceed with new legislative initiatives to permit suffering individuals to end their lives in a humane and dignified manner through physician-aid-in-dying. Perhaps the vision will be to proceed with new initiatives to address issues of pain management, suffering, and the social and economic costs of dying.

Even without legislation to improve the quality of end-of-life care or authorize physician-aid-in-dying, Hawaii is among the top-rated states in caring for dying persons. A national organization focused on end-of-life-care issues, Last Acts, recognized Hawaii as the only state to earn " $\mathrm{A}$ " grades in two aspects of caring for people at the end of their lives. ${ }^{166}$ Compared to other states, Hawaii's performance seems somewhat promising. At the same time, Hawaii received three " $C$ " grades, three "D" grades, and three "E" grades. The lowest grade was for the state's pain policy, which has subsequently been amended to allow physicians more discretion in prescribing pain medication.

Even though it may have received "good grades" from a national organization, the state's performance has been strongly criticized by the media and the public. In November 2002, the state's largest newspaper published an editorial stating that Hawaii is "lacking in the critical areas of pain management, hospice care, and death with dignity." ${ }^{167}$ Despite this criticism, the editorial concluded with an encouraging suggestion for the legislature: "[A] terminally ill person who is in chronic pain ought to have the choice to end his or her life with the help of a physician.... It's now up to the new governor and Legislature to pass laws that will make Hawaii a better place to die."168 While the latest legislative efforts failed and the governor continues to oppose PAD, public opinion and editorial opinion continue to support PAD in Hawaii. ${ }^{169}$ Perhaps in the next go-around, after the 2004 election, efforts to make Hawaii the second state to affirmatively authorize "death with dignity" may succeed.

\footnotetext{
166 Last Acts, Means to a Better End: A Report on Dying in America Today (Nov. 2002).

${ }^{167}$ Editorial, Hawaii Not Paradise for the Twilight Years, Honolulu Advertiser, Nov. 19, 2002, at A6.

${ }^{168}$ Id. In 2003, Republican Linda Lingle became Hawaii's Governor. She is opposed to PAS. The legislature, however, continues to be dominated by Democrats in both the Senate and the House and is likely to remain that way.

${ }^{169}$ See, e.g., Editorial, Terminally Ill Deserve the Right to Choice in Dying, Honolulu Star-Bull., Mar. 8, 2004, at A10; Editorial, Death with Dignity Deserves Future Look, Honolulu STAR-Bull., Mar. 13, 2004, at A11 (ended with the statement: "The proposal will be enacted only after legislators can overcome emotional opposition within their ranks.").
} 
In the meantime, improvements in palliative care and pain management must be pursued. ${ }^{170}$

Regardless of the fate of physician-aid-in-dying in the legislature, the people of Hawaii should have a voice. If proposed legislation continues to fail, then proponents could put the issue to the electorate in the form of a ballot referendum. The citizens of Hawaii should be given a chance to emulate Oregon's example or to go beyond it and reassert its own legal heritage of progressive laws on behalf of its people. As one editorial responding to the latest shelving of the death with dignity bill put it: "It's not about martyrdom, but about dignity.... Ultimately, the question of what kind of life is worth living can only be addressed by the person living that life." 171 Another editorial lamented: "We won't have the death with dignity legislation this session. And that's a shame, for what it says about both Republicans and Democrats-but most for what it means for the terminally ill." ${ }^{\prime 72}$ It might be time to stop the lamentations. It is time for patients and physicians to consider the unique provisions of Hawaii Revised Statute section 453-1 to alleviate unnecessary suffering.

\footnotetext{
${ }^{170}$ Editorial, supra note 4, at A8; see also H.B. 1839, supra note 164.

171 Id.

172 Dan Boyland, An Uneasy Death for “Dignity” Bill, MIDWEEK, Mar. 17, 2004.
} 


\section{THE JOURNAL OF LEGAL MEDICINE COMMENTARY SECTION}

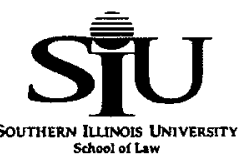

\begin{tabular}{cc}
\multicolumn{2}{c}{ STUDENT EDITORS } \\
Nicole B. Poirier & Paul M. Kaufman, Ph.D. \\
Commentary Editor-in-Chief & Assistant Commentary Editor \\
Nathaniel H. Hwang & Richard W. Kemp \\
Associate Editor (Legal Medicine & Assistant Commentary Editor \\
Perspectives) & Jennifer M. Miller \\
& Assistant Commentary Editor \\
STUDENT CONTRIBUTORS \\
Barbara Jean Bailey & Brian A. Peterson \\
Juan Carlos Gomez & Kerri B. Rubach \\
Jason H. Green & Melissa G. Steward \\
Christopher J. Levy & Rebecca Van Court \\
Monica Mikucki & Courtney Witte \\
\hline
\end{tabular}

\section{FACULTY AND STAFF}

W. Eugene Basanta

Faculty Advisor
Bonnie Miller

Secretary

The Commentary section in The Journal of Legal Medicine presents, on a regular basis, articles written by students at Southern Illinois University School of Law, Carbondale, Illinois. This feature, initiated in 1981, is designed to allow outstanding law students who have special interests in law and medicine to pursue those interests through scholarly research and publication, thereby providing readers with high-quality and timely legal commentary. 